\title{
OS DIÁRIOS DO POETA E ARTISTA PLÁSTICO MAX MARTINS
}

Paulo Roberto Vieira*

Resumo: Poeta e artista plástico, o paraense Max Martins (1926-2009, Belém-PA) produziu 48 diários entre 1982 e 1999, cadernos que fundem, por meio da colagem, sua criação poética à plástica. Na esteira do conteúdo dos diários, em cópias fac-similadas, identifiquei as linhas de força natureza, amizade e erotismo. Este artigo visa dar mostra da arte de Max Martins, no tocante à plástica e à poesia que transfiguram sua vida.

Palavras-chave: Max Martins. Diário. Poesia.

\section{INTROITO: MAX MARTINS E SEUS DIÁRIOS}

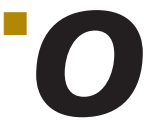

poeta e artista plástico brasileiro Max Martins (1926-2009, Belém-PA) produziu 48 diários entre 1982 e 1999, cadernos que fundem, por meio da colagem, sua criação poética à plástica, configurando um universo de apropriações de imagens verbais e não verbais que se ligam à palavra, na literatura, e aos eventos do cotidiano, nas representações plásticas. $\mathrm{Na}$ esteira do conteúdo dos diários, em cópias fac-similadas, identifiquei as linhas de força natureza, amizade e erotismo, analisadas à luz das invenções plásticas resultantes da confluência vida, poesia e imagem não verbal.

Max Martins escreveu 11 livros, entre 1952 e 2001: O estranho (1952), Anti-retrato (1960), H’Era (1971), O ovo filosófico (1975), Risco subscrito (1976), A fala entre parêntesis (1982), livro escrito com outro poeta, Age de Carvalho, Caminho de Marahu (1983), livro-pôster 60/35 (1986), Marahu poemas (1992) e Colmando a lacuna (2001). Os dois últimos iniciam, respectivamente, os ajuntamentos da obra até agora, Não para consolar (1992) e Poemas reunidos (2001).

\footnotetext{
Universidade Federal do Pará (UFPA) - Altamira - PA - Brasil. E-mail: pauloforest@gmail.com
} 
Encerra a fatura Para ter onde ir (1992). Todavia, a partir de 1982, essa produção amparou-se num gênero por meio do qual lhe era possível refletir e conjugar elementos do cotidiano e da arte. Um lugar de guardar o que na vida se coleta, lê, vê, ouve, sente, fala e silencia: o diário.

Philippe Lejeune (2008, p. 260), ao reafirmar o diário como um "conjunto de registros do cotidiano datados", põe em cena o caráter fragmentário e contingente desse tipo de relato de cunho testemunhal que capta porções, relevantes ou não, do dia a dia daquele que os escreve. No tocante às motivações que levam certos indivíduos a escrever nesses cadernos diariamente durante anos ou décadas, são os próprios diaristas que nos dão a resposta; aqueles que representam uma estranha multidão de vozes, pois o conteúdo que preenche e particulariza um diário é o que fundamenta a sua existência. A motivação está na essência do conjunto daquilo que foi redigido ao longo do tempo.

O preenchimento das páginas em um diário indica, antes de tudo, que alguém registra fatos no tempo de maneira peculiar. Um diarista trata do mundo que o rodeia a partir de referencial conhecido, mas complexo - a sua própria existência. O resultado desse experimento traz como legado uma produção extremamente rica e heterogênea. Nessa chave, os diários são o abrigo de relatos da vida que servem como fonte da experiência subjetiva e da história, além de manancial de recolhas do cotidiano que, no caso dos artistas, ligam-se ainda aos seus projetos.

Assim, a arte plástica de Max nasce do envolvimento do poeta com o gênero confessional. Aferrado à miscelânea criadora que vai do remate dos diários à peleja da invenção poética, o artista produziu centenas de colagens, desenhos e pinturas, mesclados à escrita, nos seus cadernos do cotidiano. Entre outras funções, os diários ofereciam a ele a página amiga, cúmplice, extra, imprescindivel ao poeta, e ao artista plástico se convertiam em ateliê no qual articulava figuras, objetos, tintas e palavras.

Max Martins foi um poeta na Amazônia. Nela nasceu, viveu e morreu. Poeta "na" e não "da" Amazônia, posto que a sua poesia é díspar. Destoa das escritas regionalistas pelo tom e pela atitude perante o mundo e os indivíduos, sem, no entanto, desprezar a região - telúrica, orgânica - como meio de passagem ao universal.

Dizendo de outra maneira, Max não escreveu a Amazônia, a Amazônia é que o escreveu. A essa apropriação cuidadosa dos elementos da terra liga-se a verve erótica de sua poesia. Assim, molda-se a tônica do lirismo amoroso visivel desde $O$ estranho, livro de estreia em 1952, até Colmando a lacuna, em 2001, biodiversidade em clímax tropical associada a Eros pela trama de palavras e imagens.

O poeta começou a escrever diários aos 56 anos. É de 1982 o mais antigo caderno e de 1999 o mais recente. Foram 48 diários produzidos. O artista deixou, em seu arquivo, um vultoso conjunto de manuscritos. Compõe-se a coleção, além dos diários, de mais de 20 cadernos de estudo e composição poética; de considerável soma de manuscritos avulsos de toda natureza; de vasta correspondência; e da marginália em sua biblioteca pessoal, aproximadamente dois mil títulos. O arquivo integral do poeta encontra-se, desde 2011, no acervo da Universidade Federal do Pará (UFPA). Este artigo visa dar mostra da arte de Max 
Martins, no tocante à plástica e à poesia que transfiguram a vida do escritor nos diários.

\section{LINHAS DE FORÇA E ENTROSAMENTOS NOS DIÁRIOS}

Lejeune (2008) assinala que cada diarista se situa sem dificuldades nas formas de linguagem que lhe servem de "fôrmas" para as entradas e nunca mais as abandona. Cria, assim, uma identidade expressiva no gênero. A liberdade que a página em branco do diário dá ao seu redator é pouco a pouco captada e se traduz em certas obsessões temáticas reforçadas pela regularidade das formas.

Nessa chave, três linhas de força conduzem os registros nos diários de Max Martins: erotismo, amizade e natureza. A última liga-se ao interesse do poeta pelo taoísmo, zen-budismo e pela poesia oriental - que procurou estudar e incorporar à vida e à própria criação poética desde a juventude -, mas também ao seu ambiente natural, a floresta amazônica, representada nos diários pela praia de Marahu, onde Max ergueu sua cabana.

A segunda linha temática nos cadernos transpõe as relações de amizade firmadas ao longo da vida. As ligações amicais estimulam o acúmulo intensivo de registros, criando um tom por vezes melancólico, outras vezes alegre, ligado a partidas, chegadas e saudades. A alteridade, nessa chave, atravessa os diários e deles se apossa como espaço do outro. Finalmente, o erotismo representado nesses cadernos conflui à poesia de Max e às leituras dele. Com efeito, essa tríade, em certa medida, dirige a escolha dos materiais externos coletados pelo diarista para as composições plásticas nos cadernos.

Assim, natureza, amizade e erotismo formam o substrato da atividade plástica nos cadernos de Max. Os diários tornam-se o ateliê e a galeria de exposições do artista que neles se move. Mas há ainda um movimento inverso - dos diários aos livros de poesia que o poeta publicou depois de se tornar diarista -, pois os temas e as imagens catalisados na criação plástica nos cadernos são atentamente avaliados e incorporados na poesia do "mestre-aprendiz" (NUNES, 2009) ${ }^{1}$.

\section{EsTRELAS-GUIAS E COLAGENS}

Nos diários, a colagem é, para Max Martins, o caminho, a solução para fundir a criação do poeta à do artista plástico. Deve-se realçar que no universo das apropriações das imagens verbais ou não verbais nos diários, as que se ligam à palavra, na literatura, exprimem num primeiro plano as preferências do poeta.

\footnotetext{
"Max Martins: mestre-aprendiz" foi o título dado pelo crítico e filósofo Benedito Nunes à consagradora análise que realizou
} sobre o conjunto da obra de Max Martins. 

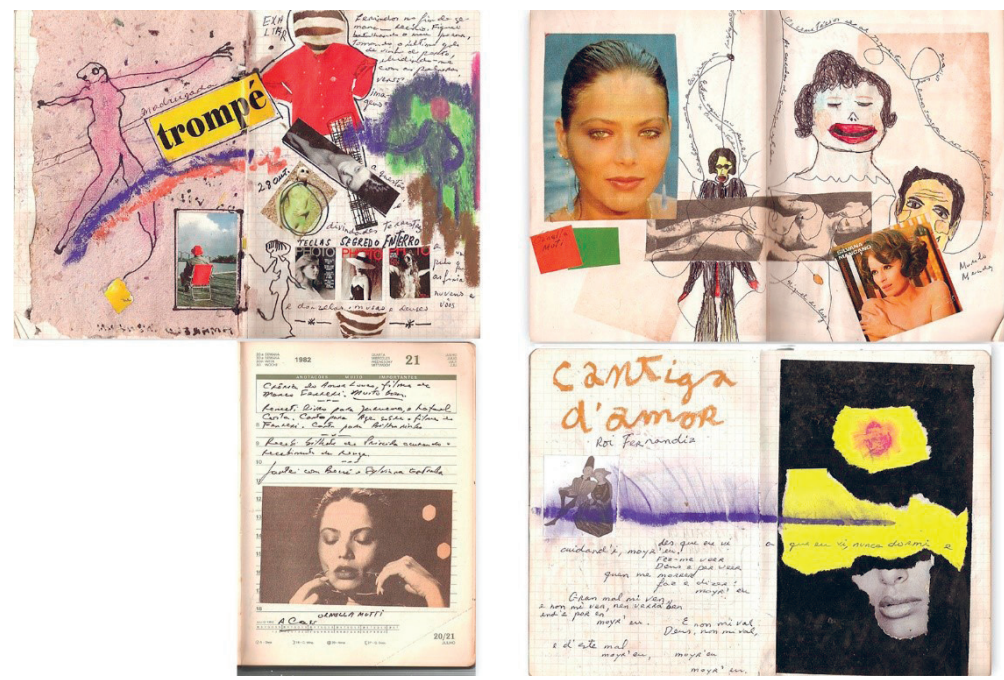

Figura 1 - Quatro fólios dos diários, da esquerda para direita em sentido horário: (D44F037² - 28 de outubro, 1997); (D13F054 - [? de janeiro], 1990); (D01F088 - 21 de julho, 1982); (D44F020 - [9 de outubro], 1997) ${ }^{3}$

São poetas, escritores, pintores, filósofos, atrizes, que constroem o panorama das leituras e apropriações literárias e plásticas de Max. Eles sobressaem nas imagens dos diários, ajudando a iluminar a história e a evolução da sua atividade poética e plástica, pois constituem opções conscientes e decisivas ao desenvolvimento do trabalho artístico dele. São as "estrelas-guias" pairando no universo das suas representações, articuladas nas páginas dos cadernos de modo a indicar caminhos à originalidade plástica e poética.

Nos diários, portanto, o artista mescla imagens verbais àquelas não verbais; por vezes, toma uma pela outra, funde-as, ao se expressar, num movimento de autoindagação, de buscas que configuram dispersão e atenção, conflito e fascínio. "Mente vazia, oficina do diabo", diz o provérbio, muito pertinente, por analogia, quando nos detemos em um trecho de poema em prosa "Carta ao Age de Carvalho", presente na única antologia de seus poemas até o momento, O cadafalso, de 2001. No poema-carta, há uma reflexão em que o artista conjectura em favor da lida poética, algo que inviabiliza à sua existência a adequação do provérbio citado. Esta lida, pela vez dela, sugere-lhe outro rifão: mente vadia, oficina da poesia:

Vivo pensando, pensar vagabundamente, poeticamente, penso nas palavras que se vão - o que quero agora? Desfazer-me das palavras, escrevendo-as, sem as sentir, a esmo, como não querendo nem tocá-las - no diário. Depois cato-as, escolho-as e nas palavras agrupadas posteriormente - dou-lhes a minha vida para que a minha vida seja delas. Do meu sangue morto, coagulado nessas palavras a esmo, intocadas, banho-as no meu sangue, no meu ser. Não quero

2 Neste artigo as chamadas das páginas fac-similadas dos diários de Max Martins seguem uma abreviatura de classificação, em que "D" e "F" significam "Diário" e "Fólio" e vêm acompanhados dos números que os determinam, seguidos de datação.

3 A figuras 1, 2 e 3, que integram este artigo, são imagens fac-similadas dos diários do poeta Max Martins, estudadas no período de meu doutorado na Universidade de São Paulo (USP), com apoio da Bolsa Fapesp, entre 2010 e 2014. A pesquisa foi autorizada pela família do poeta, falecido em 2009. 
tirar de mim as palavras, não quero nelas o meu conteúdo, a minha biografia, posteriormente. Quero uns tempos nelas, não imediato, imediatamente, imediatista, citá-las (MARTINS, 2001a, p. 165-166).

Escavação profunda na própria subjetividade, tal reflexão exibe a maneira quase solene de se apropriar das palavras; as imagens como força externa motivadora do gesto criador, em que a coexistência com os vocábulos leva a uma relação orgânica e simbiótica. O mecanismo da arte mostra ao artista convivência, demorada e produtiva, com as palavras, feito o trabalho das epífitas na floresta. O poeta, no diário, nutre sua poesia sem parasitar a fonte, quer apenas um tempo nas palavras - é hóspede delas - como as orquídeas que vivem nas árvores.

Ao mesmo tempo é visivel a busca de certa distância das palavras que, intocadas, são "banhadas" no sangue dele, no seu ser. A distância que o artista pretende visa a uma aproximação futura, equilibrada, decisiva e consciente das palavras (e das imagens delas decorrentes), pois planeja para depois, no diário, catá-las, escolhê-las, agrupá-las, e a elas dar a própria vida. O poeta quer sua ontologia nas palavras, quer cultivá-las e ser parte delas.

Esse extrato do poema, portanto, revela dois fatores-chave no processo criativo de Max. Primeiro, indica uma das principais origens da economia verbal percebida na poesia dele. As palavras, vistas de longe, cultivadas, pedem a ele o tempo de se mostrarem. Em média, o intervalo entre a publicação dos livros de Max gira em torno de dez anos. Além disso, são obras de reduzido número de páginas; seus poemas reunidos, ao final de 50 anos de ofício ininterrupto, não chegam a 350 páginas.

A segunda revelação importante nesse trecho de poema em prosa é o sentido central dos diários na manutenção da poesia: "Desfazer-me das palavras escrevendo-as", diz e conclui o poeta, "no diário". Ali as palavras estão a salvo, paradoxalmente distantes do diarista e perto o suficiente para serem conquistadas, apreendidas e incorporadas ao "eu" que fala na poesia.

Os diários de Max não possuem ilustrações: são registros plasmados na estreita união da palavra com a plástica, que viceja na feliz fusão do desenho com a colagem. As palavras vêm na tinta de canetas esferográficas e hidrográficas; os desenhos, na mesma tinta, em lápis de cor e lápis-cera, pastel, ligando-se às colagens, presentes em quase todas as páginas.

Nessa dinâmica, Max construiu, nos diários, traduções associativas que expressam preferências pessoais, mas também aprofundam lições estéticas que envolvem, em certa medida, traços culturais das imagens verbais e não verbais associadas.

Assim, Max baliza as tendências do seu projeto e, ao mesmo tempo, vê o próprio rosto espelhado nas constelações que organiza, pois há, nas escolhas além da expressão da liberdade -, a construção e a consolidação da própria identidade, tendo em conta que a identidade se constrói por meio do diálogo com o "Outro". Dessa maneira, as apropriações, em qualquer que for a lingua ou linguagem, ocorrem numa dinâmica da autorreflexão - do pensar o próprio ser - não apenas por meio dos sentidos extraídos nas leituras e no ver, mas também pelos significados nascentes nas articulações entre verbal e não verbal.

O fato de interessar-se por tudo como novidade, porém, é o ponto de partida da criação artística de Max Martins. E isso se dá como um regresso momentâneo 
ao estado de infância, em que as minúcias do objeto mais simples inebriam o espírito. Baudelaire (2006, p. 856), em O pintor da vida moderna, afirma: "Nada se parece tanto com o que chamamos inspiração quanto a alegria com que a criança absorve a forma e a cor". Se, no adulto, a razão ocupa espaços consideráveis da vida, na criança, a sensibilidade rege quase toda a existência. Um artista que de tudo se ocupava com uma curiosidade infantil em estreita aliança com a imaginação, eis o traço biográfico chave por trás do encantamento que esses diários proporcionam. Preocupação central nos diários de Max - que abarca todas as demais preocupações -, a colagem foi, para ele, o ambiente perfeito à articulação criadora envolvendo literatura e imagem não verbal, confissão e segredo, palavra e objeto, mundo "real" e mundos imaginados.
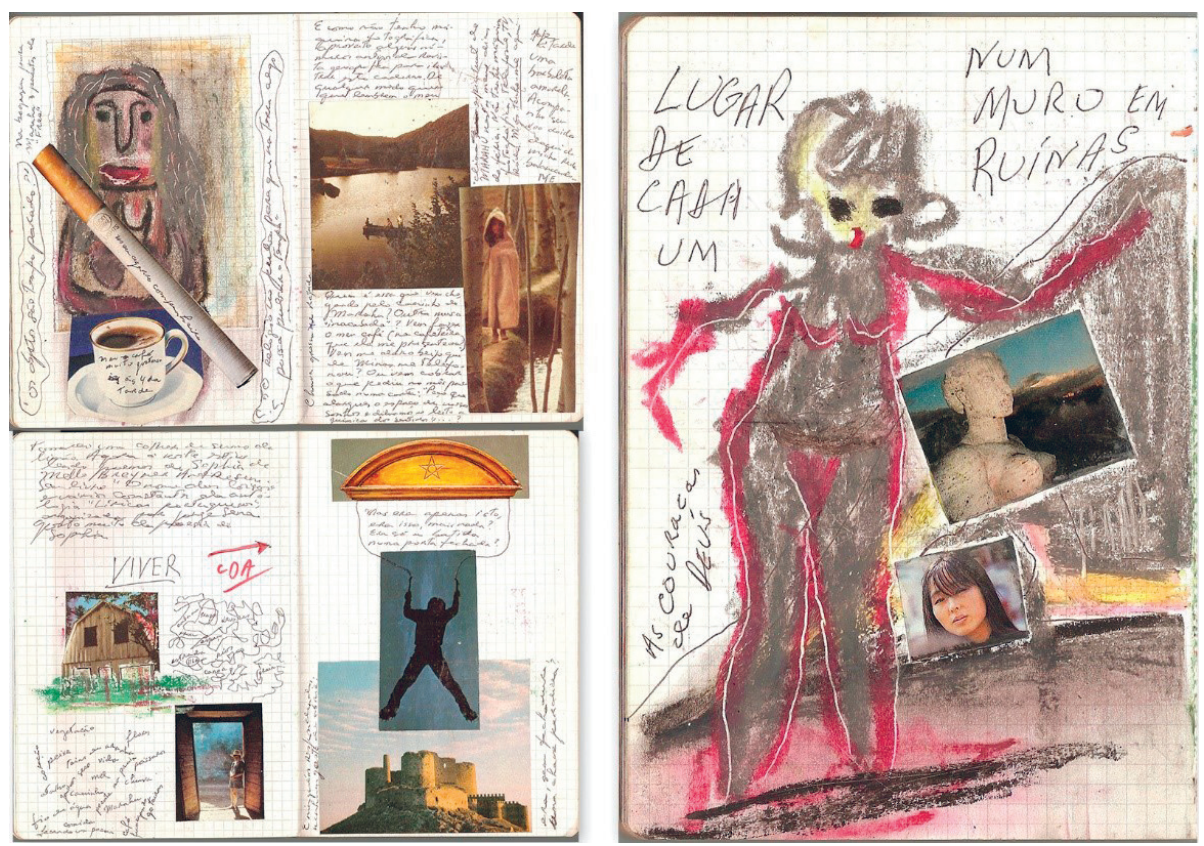

Figura 2 - Três fólios dos diários, da esquerda para direita em sentido horário: (D32F010 - [? de agosto], 1994); (D32F071 - [? de setembro], 1994);

(D32F005 - [? de agosto], 1994)

\section{EROTISMO}

Por meio da carnalidade, as imagens nos versos de Max Martins reconfiguram a natureza - que assume um porte transcendental -, em que metáforas trazem à tona todos os entrelaçamentos da linguagem e do sexo que o poeta articula. Contudo, ao dissecar essa poética, Benedito Nunes (2009, p. 353) esclarece que, nela, "vislumbra-se uma indecisão no regime das imagens e uma oscilação na consolidada conivência de Eros e Poiesis, que denunciam uma crise do pessimismo trágico".

Num gesto criativo, o poeta situa tal lirismo quando escreve, no livro $H^{\prime} E r a$, os versos: "Este rio enorme, paul de cobras / onde afinal boiei e enverdeci/ amei/ 
e apodreci" (MARTINS, 1971, p. 20). Na poesia de Max, essa crise culmina numa espécie de degradação não apenas do corpo, mas também do ser, à força de um contraditório apodrecimento; de uma decomposição orgânica. Todavia, a autodegradação tende não à extinção, mas à reintegração tortuosa, autoaniquilante e difusa ao ambiente da natureza.

O erotismo é sempre uma convocação à vida, pois simula compleição de eternidade nas ações que, contraditoriamente, entram em declínio e se mostram fugazes após o ápice extático. No caderno, o diarista quer cristalizar a ideia da carne e da sedução como beleza e motivo perenes da poesia e da existência. Assim, as articulações eróticas nos diários de Max Martins servem de simulacros à sobrevivência do corpo diante da incontornável consumação desse mesmo corpo. Nessa poesia, a ação é concebida em termos corporais e vegetais, pelos quais se aprecia a sexualização da natureza e a naturalização do erotismo. É uma poesia cíclica, muito ligada à fertilidade, na representação de Eros e também de Gaia, posto que uma poética de desejo e de terra.

Nessa conjugação entre o mundo vegetal e o erotismo da poesia, os diários de Max tornaram-se o ambiente da comunhão entre a esfera carnal e a esfera espiritual, que tende ao aniquilamento. Nesses cadernos, a poesia serve de manancial do pensamento, e o mundo ali representado frequentemente traz as marcas de um lirismo desolador.

O diarista, por meio do manejo de representações femininas e imagens verbais, alude ao prazer ligando-o ao ato escritural e plástico. Assim, no plano do diário o poeta simula um mundo erotizado, em que o eu lírico da poesia - como as mulheres representadas - também se "expõe", mas procurando, frequentemente, revelar os anseios do eu do diarista. Todavia, isso configura a busca do entendimento do prazer e da função das obsessões. O diário passa, em certa medida, a representar o lugar de experimentação de formas líricas e eróticas e de reflexões íntimas que mesclam passagens da vida e pensamento poético.

Sabe-se que é função da arte poética simular o improvável. Na ilustração valorizada por meio de imagens, a poesia, por vezes, oferece aquilo que nos é vedado ter. Arte de revelar ocultando e de ocultar revelando, a poesia tem por mecanismo fazer-nos almejar algo para, num corte, nos abandonar na ausência do apenas pressentido. Todavia, "o papel é um espelho" (LEJEUNE, 2008, p. 236). Essa metáfora de Lejeune, referindo-se aos diários e seus redatores, ajuda a destacar os cadernos como espaço da introspecção, análise e conhecimento do eu. Nessa dinâmica, os jogos representados por meio da referência ao erotismo nos diários de Max são ainda espelhos paradoxalmente turvos da existência porque, como a poesia, simulam o alcance do improvável e lançam o diarista - sob disfarce - ao centro das obsessões e dos desejos, talvez, inatingiveis.

Nos diários, a arte erótica veicula - sob a égide fálica ligada ao corpo feminino - o trabalho reflexivo do diarista com a matéria da poesia. Com efeito, Eros está no centro das tramas plásticas e da linguagem, enquanto o poeta diarista simula ambientes de encantamento que no fundo exprimem desencantos líricos. A relação de Max com essas palavras e imagens nos diários é tão contemplativa quanto ativa e as articulações resultantes são atos plásticos que, por vezes, constituem um conflito de atitudes. Assim, o eu dos diários se faz personagem nesses arranjos que fundem testemunhos, confissões, imagens, palavras, o que alivia, nessas projeções e transfigurações, a dor do sujeito real que tenta se esgueirar nas páginas. 


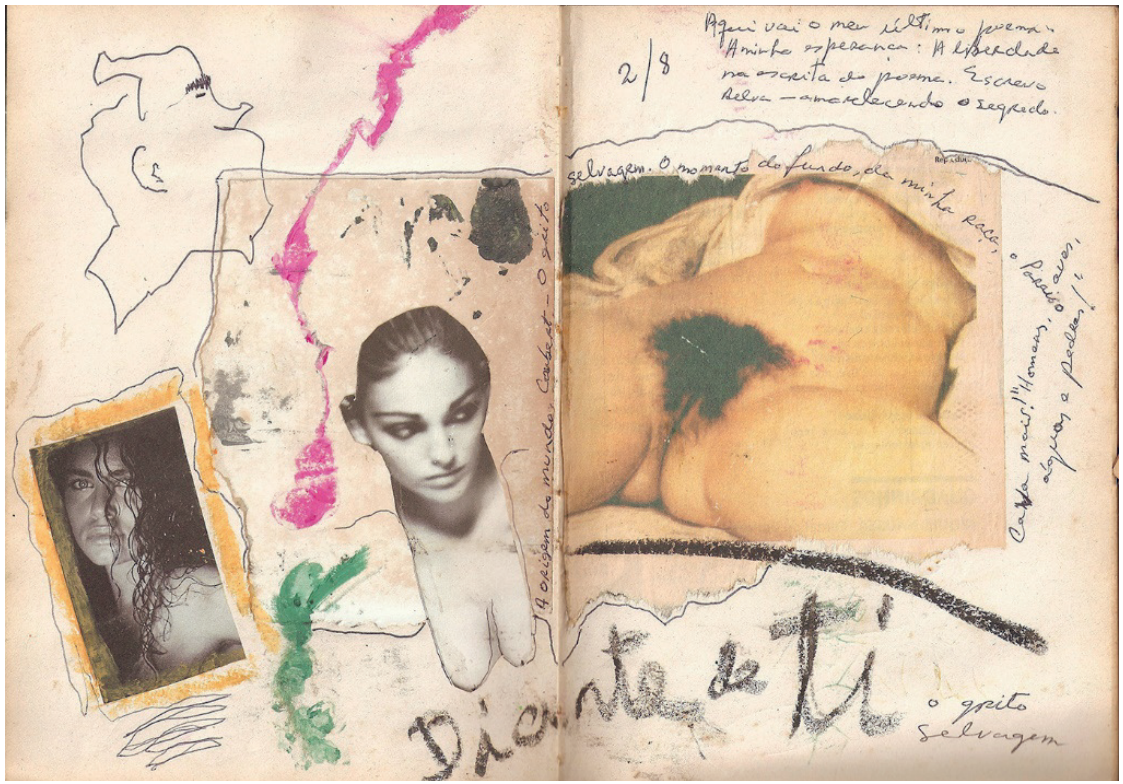

Figura 3 - Fólios dos diários (D43F007 - 2 de agosto, 1997)

\section{NATUREZA, A CABANA}

Sabe-se que Max Martins começou a aventura de escrever diários em 1982. Entretanto, como vimos, erotismo e natureza já coexistiam e se combinavam na poesia dele desde o início, em meados de 1950. Mas qual a essência dessa natureza que o diarista relaciona ao erotismo nos versos e nos diários? Na leitura da poesia publicada e dos cadernos, vê-se ainda que a tônica da natureza incorporada se liga intimamente ao gosto pelos haicais e ao estudo do taoísmo e do zen-budismo, realizado pelo poeta desde a juventude, mas também se vincula ao seu próprio ambiente natural - a floresta amazônica - nos diários e na poesia representada pela praia de Marahu.

Assim, Marahu, distante cerca de 70 quilômetros de Belém, no Pará, tornou-se o principal cenário do entrosamento entre Logos e Eros na poesia de Max Martins. Os reflexos das estadias do poeta na praia não demoraram a se traduzir em versos. Em 1983, é publicado Caminho de Marahu, que traz os primeiros poemas de beira-rio, e, em 1986, o livro-pôster 60/35 - 60 anos de vida e 35 de poesia - que, em admirável arranjo, associa poemas a fotografias de Max na praia ${ }^{4}$. Mas o vigor desse ambiente se fez manifesto ainda nos livros ulteriores, Para ter onde ir, em 1992, Marahu poemas - seleção de inéditos que inicia a primeira reunião dos poemas de Max, Não para consolar, nesse mesmo ano - e, por fim, a parte Colmando a lacuna, abrindo Poemas reunidos, em 2001.

Passei uma época muito ligado ao zen-budismo, ao taoísmo. As melhores leituras que tive foi ao ler as anedotas, os paradoxos zen-budistas. Aprendi que o

\footnotetext{
4 O projeto gráfico do livro-pôster 60/35 é do poeta e designer Age de Carvalho e as fotografias de Octávio Cardoso.
} 
melhor que temos a fazer é fazer o que devemos fazer. Não ir para o lado esquerdo, não ir para o lado direito, mas caminhar passo-a-passo para frente (MARTINS, 1999).

Devo, neste ponto, recapitular elementos desses caminhos filosóficos de Max Martins, para melhor compreensão deles. Nascido no Oriente, o budismo busca difundir os ensinamentos de Siddhartha Gautama, o Buda, que viveu entre os séculos VI e IV a.C. Por sua vez, Zen é uma prática religiosa que consiste na meditação contemplativa de autoinstrução e autoconhecimento, por meio da observação da própria mente. Meditar é seguir a respiração, abrir-se ao vazio, deixar-se longe de aflições e ansiedades, acalmar-se, numa tentativa de se evadir dos conflitos ao encerrar a ação do pensamento.

Outros ensinamentos de tradição chinesa, que abarcam a filosofia, a religião e a poesia, estão no taoísmo. Trata-se, sobretudo, de um modo de ver a vida como caminho que se abre à natureza. Seus ensinamentos foram condensados em Tao-Té-Ching - o livro do caminho perfeito (LAO-TSÉ, 1973), cuja autoria é atribuída a Lao-Tsé, personagem lendário, que teria vivido entre 570-490 a.C. A obra compõe-se de máximas e aforismos que buscam interpretar o mundo e os homens com o propósito de uni-los e envolvê-los numa atmosfera harmônica e de profunda compreensão.

Tao é o caminho perfeito. Para o taoísmo, essa palavra é intraduzivel. Expressão do constante movimento do Universo. É algo intangivel, inexplicável. Para entendê-lo, é preciso colocar-se em sintonia com ele, senti-lo. A melhor imagem que pode talvez ilustrar o caminho perfeito é a da linha que oferece a menor resistência entre dois pontos.

Com efeito, Tao é o movimento dos astros celestes, o pipilar dos pássaros, o correr do rio na terra, o percurso que as gotas de chuva traçam após tocarem a copa das árvores, deslizando pelas folhas, pecíolos, galhos, aproveitando as ranhuras dos fustes para alcançar a "receptiva terra"5 (MARTINS, 1990, p. 11), depois de percorrer um caminho que reflete com sabedoria o menor esforço.

Além de se interessar pelos ensinamentos orientais desde a juventude, Max também leu Auden (THOREAU, 2010), do poeta anarquista e naturalista norte-americano Henry David Thoreau (1817-1862). Ao propor um retorno à vida simples, essa obra autobiográfica contém tanto uma declaração de autoindependência quanto uma experiência social, que configura uma viagem de descobertas espirituais. Em 1845, Thoreau retirou-se para a floresta, inspirado na filosofia de Confúcio - contemporâneo de Lao-Tsé.

Ainda no que concerne a Auden, é preciso dizer que a atitude de Thoreau perante o mundo faz lembrar, em certa medida, a de outro poeta, igualmente anarquista e norte-americano, que conviveu com Max e seu grupo em Belém no início dos anos 1950: Robert Stock, o Homem da Matinha, como era conhecido, porque morava em uma choupana de chão batido, no antigo bairro assim denominado. Essa convivência intelectual, que durou cerca de três anos, marcou profundamente a poesia de Max.

Assim, Thoreau e Stock, ambos "from USA", pela atitude anticonsumista e desprendimento material perante o mundo, principios fundadores da "beat generation" - gérmen do movimento "hippie" -, coadunam com o desapego em favor do 
espírito professado nos ensinamentos de Buda, Lao-Tsé e Confúcio. Insira-se ainda, na poção da alquímica experiência de Max Martins, o seu estudo do oráculo chinês, uma das faces do milenar I Ching, o livro das mutações (WILHELM, 1956).

Essa relação evidencia-se, com maior rigor, no livro Para ter onde ir (1992), inteiramente escrito segundo as regras do jogo ritual, que consiste na formulação de perguntas ao oráculo. O poeta entregou os sentidos ao acaso, interessado nas revelações proporcionadas pelo I Ching com sua linguagem simbólica, não verbalizada, que se relaciona à manifestação do inconsciente.

Nos diários, como na poesia, o desejo surge como ânsia de complementação do eu. Trata-se de um processo compensatório, em que o diarista se projeta naquilo que almeja. Está constantemente sugando aquilo que deseja e não alcança. Nessa dinâmica, os ensinamentos do Tao parecem atuar no entendimento das virtudes do desapego, da inação, que leva ao equilíbrio e à autossuficiência. O diarista conjugava esses elementos nas articulações nos cadernos visando alcançar uma continuidade de consciência à vida cotidiana.

\section{Amizade nOS DIÁRIOS}

No tocante às relações de amizade, o diário de Max serve como espaço da alteridade, conjugada ao inelutável pensamento sobre a solidão e a velhice, bem como, e paradoxalmente, à reflexão sobre a conquista de uma espécie de segunda juventude vivida e celebrada na velhice. Isso porque a década de 1980 configura para Max, adentrando os "sessenta anos-sonhos" (MARTINS, 1992, p. 19)", o momento da plena maturidade pessoal associada à juventude dos novos amigos que o rodeiam e admiram.

A amizade não possui uma denotação objetiva, é algo "transcendente" que significa simplesmente o ser. Assim, no ensaio $O$ amigo aventa o filósofo Giorgio Agamben (2009, p. 92):

Os amigos não condividem algo, (um nascimento, um lugar, uma lei, um gosto) eles são com-divididos pela experiência da amizade. A amizade é a condivisão que precede toda divisão, porque aquilo que há para repartir é o próprio fato de existir, a própria vida.

Assim, configura-se uma espécie de partilha sem objetos. Portanto, nos diários, a experiência do prazer, da alegria e da felicidade proporcionadas no convívio daqueles amigos, por vezes, estava justamente em ser com o outro.

[...] Marcinha carinhosa, terna, dadivosa. O trio feliz: / eu, ela, Age. Identidade, afetividade. Doces em nossas sensibi- / lidades. Os três quase um só. União. A palavra para os / três hoje no café foi: HARMONIA. Comunhão de carências. / Alegrias íntimas. Bebemos, comemos. Os três lírica- / mente bêbados. Os corações livres, libertos da / alienação do dia-a-dia e plenos de uma comunhão / fraterna de nossos eus. No café a / nossa solidão, a querida solidão a três, um só egoísmo / - os três em um, desligados de todo o resto do pessoal / ali. Cada um de nós voltado unicamente / para nossa harmonia. Mesmo quando falávamos / dos outros, de outras pessoas, ou de fatos do "outro / mundo". Só nos interessava o som de nossas vozes, um / para o outro. Entre nós não havia a mínima / distância, nenhuma ponte. / A distância, as individualidades tinha /

6 Verso do poema "O caldeirão". 
sido absorvidas, naturalmente. Algumas horas / raras de nossas vidas. Bonito. / Da para acreditar na vida. Que valeu a / pena termos e estarmos vivos. / Lépidos e levemente bêbados na madrugada / cambaleávamos em flor pela avenida. / estávamos abençoados pela terna / compreensão da noite, da natureza inocente / e feliz (D09F098 - 23 de dezembro de 1988).

Para Max Martins, as amizades são dignas de memórias e o diário é para onde elas confluem. No Diálogo sobre a amizade, de Cícero (1930, p. 15), em que o filósofo discute a fundo as relações amicais no seu tempo, o narrador, Lélio, diz do amigo Cipião (o Africano), que perdera para a morte: "a lembrança da nossa amizade é para mim tão grata, que tenho por felicidade o viver por haver vivido com Cipião".

Max, nesse trecho de diário, refletindo o encontro daquela noite no café, expressa um sentimento que, de certa maneira, corresponde ao de Lélio, mas, no caso do poeta, a mesma plena compreensão dos sentidos da amizade aparece enquanto ele ainda está junto dos seus - "Dá para acreditar na vida. Que valeu a / pena termos e estarmos vivos. / Lépidos e levemente bêbados na madrugada / cambaleávamos em flor pela avenida".

Nos diários de Max Martins, para além dos processos de criação poética e das articulações plásticas que se entrosam e ressignificam o cotidiano nas páginas, o diarista coloca as amizades sobre todas as conivências da vida, porque sabe que nada é tão conforme à natureza, nem tão a propósito para os casos favoráveis ou adversos da existência quanto as relações amicais.

Norberto Bobbio (1997) reflete acerca do significado da vida ao observá-la da senescência, aos 87 anos, em O tempo da memória: de Senectute e outros escritos autobiográficos. Contemplando o próprio passado, Bobbio (1997, p. 18) lembra que, psicologicamente, sempre se considerou um pouco velho, mesmo quando jovem, e vice-versa: "Fui velho quando era jovem e quando velho ainda me considerava jovem até há poucos anos".

O filósofo italiano reitera que exercem importância determinante sobre esses estados de ânimo as circunstâncias históricas, aquilo que acontece à nossa volta, tanto na vida privada como na vida pública. Deve-se dizer que o começo da velhice para Max Martins trouxe, além do apuro nas memórias de fatos relevantes - contraditoriamente cada vez mais longe, no passado - um inesperado acontecimento: novos e decisivos amigos cheios de mocidade.

Assim falava Zaratustra: "Eu e Mim estão sempre em conversação demasiado veemente. Como poderia suportar isso se não houvesse um amigo?" (NIETZSCHE, 2007, p. 83). Porque nos traz o lastro e a carga da maior parte da existência já transcorrida, na velhice pode-se aspirar desconhecidos ares em novos amigos que - para além dos entes já consagradas no tempo -, jovens, transpiram frescor, avidez, confiança e curiosidade naquilo que ainda desconhecem da vida.

Todavia, não se trata simplesmente de "aquele" completar "neste" alguma lacuna, ou de um tomar para si parte da carga que o outro acumulou nos anos e décadas. Nietzsche (2007) afirma que o amigo é sempre o terceiro, quer dizer, aquele que significa a válvula impedindo os outros de se abismarem nas profundidades. Esse terceiro tem vida própria, está fora dos amigos dos quais provém. Assim, a amizade pode ser entendida como algo externo que os amigos devem alimentar e manter, qual seja, a própria relação. A amizade, portanto, não pertence nem a um nem a outro, mas respira entre eles. 
Na senilidade pode surgir a melancolia subentendida como consciência do não realizado e do não mais realizável. Essa melancolia é suavizada nos afetos que o tempo não consumiu (BOBBIO, 1997). Se a velhice dura pouco, é justamente por isso que nasce um sentimento de urgência. Associa-se o medo de a estrada estar perto do fim à esperança de prolongá-la, de ir além, de alcançar outras paragens. "O tempo acumulando-se sobre os ombros pesa", mas, incansável, o poeta quer seguir adiante:

Tanta coisa para fazer /O TEMPO / acumulan- / do-se sobre / os meus om- / bros PESA, / pesa prá / caralho. / tantos livros / novos para / ler. / O universo / é mais / maior do / que eu / pensava. / Ir ali, / acolá, / fazer, / providenciar tais e tais coisas, amar, / não-amar. E não esquecer nada. / Tudo tem de estar na ponta dos / dedos, na ponta da língua. / Meu Deus! São tantas as coisas / a pensar, pensar, dizer, silenciar, anotar para lembrar. / Este trem veloz, velocíssimo / que me leva rápido, rápido / para... para NUNCA MAIS... / fatos, coisas, imagens / afagos, beijos, poemas, / encontros ACABANDO / de repente. Age já se / foi há uma semana, Aonde vamos parar? / Preciso adiar-me, / desfiar mais as estações / viver um pouco / mais devagar / A cabana passou? Está parali- / zada. Um novo livro de / poemas também tem pressa. / É urgente escrever - Rápido / para o Jim, Rose Estela, / Margaret, Márcia, enviar meus livros para Ute Hermann / beijar Rose Risueño, ir à Estrela (D41F006 e F007 - 29 de agosto de 1996).

Nessa última passagem do caderno, Max Martins ainda se indaga e se compreende, mas já não se disfarça. Agarra-se ao diário e às representações da alteridade - que nele cultivou por cerca de 20 anos - e procura extrair daí a força, a coragem e o ânimo para continuar a jornada da existência. O poeta se pergunta ainda, "A cabana passou?", e logo responde, "Está paralisada". Benedito Nunes (2012, p. 319), amigo fundamental e melhor intérprete do poeta com quem compartilhou a juventude e a velhice, diz da poesia de Max algo que se pode aplicar também aos seus diários: "as vivências passadas, as lembranças particulares, transformam-se em episódios de uma só anamnese confundida com o ato de escrever".

Assim, enquanto o mestre aprendiz confessa no diário as saudades de Marahu, da cabana - que representa a natureza e a evasão; o escape do tempo opressor -, transmite ainda uma autossondagem existencial que revela a transcorrência e a proximidade do fim de uma vida que experimentou plenitude e verdade, uma existência paradoxalmente deslocada e, com todas as forças, agarrada ao "mundo real".

\section{The NOTEBooks OF THE POET AND ARTIST MAX MARTins}

Abstract: Max Martins, poet and artist from Belem do Para, Brazil, was born in 1926 and died in 2009. He wrote/illustrated 48 journals between 1982 and 1999, notebooks filled with collages, a source for his poetic and pictorial creations. Using the actual notebooks and some digital facsimiles, I sought to classify and organize the material. Three central themes emerged: the power of Nature, Friendship, and Eroticism. This article shows how Max Martins transformed his life into art from the pictures and the poetry in the notebooks.

Keywords: Max Martins. Notebooks. Poetry. 


\section{REFERÊNCIAS}

AGAMBEN, G. O que é contemporâneo e outros ensaios. Tradução Vinícius Nicastro Honesko. Santa Catarina: Argos, 2009.

BAUDELAIRE, C. Poesia e prosa. Tradução Ivan Junqueira. Rio de Janeiro: Nova Aguilar, 2006.

BOBBIO, N. O tempo da memória: de Senectute e outros escritos autobiográficos. Tradução Daniela Versiani. Rio de Janeiro: Campus, 1997.

CÍCERO, M. T. Diálogo sobre a amizade. Tradução José Perez. São Paulo: Cultura Moderna, 1930.

LAO-TSÉ. Tao-Té-Ching - o livro do caminho perfeito. Tradução Murilo Nunes de Azevedo. Rio de Janeiro: Civilização Brasileira, 1973.

LEJEUNE, P. O pacto autobiográfico: de Rousseau à internet. Tradução Jovita M. G. Noronha. Belo Horizonte: Editora UFMG, 2008.

MARTINS, M. H’Era. Rio de janeiro: Saga, 1971.

MARTINS, M. Para ter onde ir. São Paulo: Augusto Massi e Massao Ohno, 1990.

MARTINS, M. O jardim zen de Max Martins. Belém, mar. 1999. Entrevista concedida a Ney Paiva. Disponível em: <http://hospiciomoinhodosventos.blogspot. com.br>. Acesso em: 10 jan. 2013.

MARTINS, M. O cadafalso. Belém: Cão Guia, 2001a.

MARTINS, M. Poemas reunidos (1952-2001). Belém: Cejup, 2001b.

NIETZSCHE, F. Assim falava Zaratustra. Tradução Mário Ferreira dos Santos. Rio de Janeiro: Vozes, 2007.

NUNES, B. A clave do poético. São Paulo: Companhia das Letras, 2009.

NUNES, B. Do Marajó ao arquivo: breve panorama da cultura no Pará. Belém: Secult-PA, EDUFPA, 2012.

THOREAU, H. D. Auden. Tradução Denise Bottmann. Rio de Janeiro: L\&PM Pocket, 2010.

WILHELM, R. (Org.). I Ching, o livro das mutações. Tradução Alayde Mutzenbecher e Gustavo Alberto Corrêa Pinto. São Paulo: Pensamento, 1956. 